\title{
State Obligations to Counter Islamophobia: Comparing Fault Lines in the International Supervisory Practice of the HRC/ICCPR, the ECtHR and the AC/FCNM
}

\author{
Kristin Henrard*
}

\section{Abstract}

Islamophobia, like xenophobia, points to deep-seated, ingrained discrimination against a particular group, whose effective enjoyment of fundamental rights is impaired. This in turn triggers the human rights obligations of liberal democratic states, more particularly states' positive obligations (informed by reasonability considerations) to ensure that fundamental rights are effectively enjoyed, and thus also respected in interpersonal relationships. This article identifies and compares the fault lines in the practice of three international human rights supervisory mechanisms in relation to Islamophobia, namely the Human Rights Committee (International Covenant on Civil and Political Rights), the European Court of Human Rights (European Convention on Human Rights) and the Advisory Committee of the Framework Convention for the Protection of National Minorities. The supervisory practice is analysed in two steps: The analysis of each international supervisory mechanism's jurisprudence, in itself, is followed by the comparison of the fault lines. The latter comparison is structured around the two main strands of strategies that states could adopt in order to counter intolerance: On the one hand, the active promotion of tolerance, inter alia through education, awareness-raising campaigns and the stimulation of intercultural dialogue; on the other, countering acts informed by intolerance, in terms of the prohibition of discrimination (and/or the effective enjoyment of substantive fundamental rights). Having regard to the respective strengths and weaknesses of the supervisory practice of these three international supervisory mechanisms, the article concludes with some overarching recommendations.

Keywords: Human rights, positive state obligations, islamophobia, international supervisory mechanisms

\section{Introduction: Islamophobia, Human Rights Implications and Related Positive State Obligations}

The increasing incidence of Islamophobia in the Western world, not in the least since the terrorist attacks of $9 / 11$, and the violent attempts to establish an Islamic State (ISIS), ${ }^{1}$ has been difficult to ignore. Notwithstanding the abundant literature on Islamophobia, no generally agreed upon definition can be identified. ${ }^{2}$ Nevertheless, in its core, Islamophobia refers to prejudice against Muslims and, by way of translation of this state of mind, actual intolerant attitudes towards Muslims, ultimately resulting in policies and practices that target and discriminate against Muslims. ${ }^{3}$ Importantly, Islamophobia does not merely concern discrimination on grounds of belief, but often concerns intersectional discrimination, that is discrimination on a combination of grounds. ${ }^{4}$ Muslims are indeed not only defined in terms of their religious affiliation but also in terms of their assumed ethnicity, the exact dividing line between

1. See, inter alia www.theguardian.com/world/isis. Several reports by prominent non-governmental organisations (NGOs), as well as various bodies of the Council of Europe, and the European Union (EU)'s Fundamental Rights Agency document on the worrying trend of multiple manifestations of intolerance against Muslims: see, inter alia, Ernes Bayrakli and Farid Hafez, European Islamophobia Report 2017 (SETA 2018), Parliamentary Assembly of the Council of Europe (PACE), Islam, Islamism and Islamophobia in Europe (Resolution 1743) Council of Europe 2010; inter alia EU High Level Group on Combating Racism, Xenophobia and Other Forms of Intolerance, available at: https:// ec.europa.eu/newsroom/just/item-detail.cfm?item_id=51025 (last visited 30 September 2019). See also EU Midis II Main Results (Second EU Minorities and Discrimination Survey), available at: https:// fra.europa.eu/sites/default/files/fra_uploads/fra-2017-eu-midis-iimain-results_en.pdf (last visited 30 September 2019), at 64-5.

2. A definition which is well regarded is the one by the British race relations NGO the Runnymede Trust, that coined the term in 1997 in the report 'Islamophobia: A Challenge for Us All'.

3. E. Bayrakli and F. Hafez, European Islamophobia Report 2017 (SETA 2018), at 25.

4. T. Makkonen, Multiple, Compound and Intersectional Discrimination: Bringing the Experiences of the Most Marginalised to the Fore, Turku, Abo Akademi (2002), at 9. 
religious and ethnic elements of group identity often difficult to separate. In this respect, Islamophobia has been described as a particular kind of racism targeting Muslims, acknowledging that religion plays a weighty role in xenophobia. ${ }^{5}$ Furthermore, when Islamophobic measures are directed towards the wearing of religious clothing, this tends to affect predominantly women, thus potentially combining three grounds of discrimination: religion, race and gender. ${ }^{6}$

Furthermore, it is important to realise that an instance of discrimination does not only affect the right not to be discriminated against, as a distinct fundamental right, but often also disproportionately limits the enjoyment of other fundamental rights. Having a closer look at the broad range of manifestation of Islamophobia helps clarify the potentially far-reaching human rights implications of Islamophobia. ${ }^{7}$ Discriminatory violence against Muslims may fall in the scope of application of the prohibition of torture and inhuman and degrading treatment (or the right to respect for privacy, as encompassing respect for the physical integrity). Discrimination infused by Islamophobia can also block one's equal and effective access to education, employment or public services, because of one's (assumed) Muslim identity. Such instances of direct discrimination jeopardise Muslims' equal participation in society. ${ }^{8} \mathrm{~A}$ disproportionate limitation on the freedom to manifest Islam in public, and, more particularly, when the manifestation concerns the wearing of religious garments, ${ }^{9}$ or the eating of halal food or respecting prayer times, can also be infused by Islamophobia. ${ }^{10}$ The related violation of the freedom of religion and the more latent, more hidden, more indirect discrimination also limits one's equal and effective access to education, to employment and even to public space at large, thus similarly translating into the violation of multiple overlapping fundamental rights and undermining Muslims' participation in society. ${ }^{11}$ ECRI General Policy Recommendation no 5 on combating intolerance and discrimination against Muslims confirms this broad understanding of Islamophobia as interrelated with multiple human rights violations, constitut-

5. Ibid.

6. See HRC, Sonia Yaker v. France, CCPR/C/123/D/2747/2016, 17 July 2018, at para. 8.17.

7. See also preamble of ECRI General Policy Recommendation no 5 on combating intolerance and discrimination against Muslims. See also I. Trispiotis, 'Islamophobia as a Key Contextual Factor in Human Rights Adjudication', in I. Law et al. (eds.), Countering Islamophobia in Europe (2019), at 9.

8. See in this regard the reports, above n. 1.

9. The Council of Europe's Parliamentary Assembly has noted with concern the negative stereotypes about Muslim women in the debate about the Islamic headscarf and veil: see, inter alia, PACE Resolution 1887.

10. The UN Human Rights Council does not only explicitly recommend states to foster a domestic environment of religious tolerance, peace and respect (Human Rights Council Resolution 16/18, Combating intolerance, negative stereotyping and stigmatisation of, and discrimination, incitement to violence and violence against, persons based on religion or belief, A/HRC/RES'16/18, 12 April 2011, at para. 5) but also highlights in this respect the importance of the effective protection of religious minorities' freedom to manifest their religion (ibid., at para. 6b).

11. See infra on S.A.S. v. France. ing 'a multifaceted problem of restricted religious freedom, religious and intersectional discrimination and social exclusion'. 12

The often far-reaching human rights implications of Islamophobia invite liberal democracies to counter Islamophobia, given their commitment to respecting fundamental rights throughout their policies and activities. In addition to states' negative state obligations not to engage in Islamophobic policies and acts, states also have a variety of positive state obligations, aimed at ensuring that fundamental rights are effectively enjoyed, also in horizontal, interpersonal relations. ${ }^{13}$ This article sets out to analyse and compare the positive state obligations to counter Islamophobia that are identified by selected international supervisory mechanisms of relevant human rights conventions.

The following paragraphs of this introduction not only expand on the notion of positive state obligations and their relation to the effectiveness principle but will also reflect on the notion of 'countering Islamophobia' as encompassing both countering a state of mind and countering acts/policies informed by that state of mind. This in turn triggers the question whether human rights requires states to change the hearts and minds of their subjects. The introduction then proceeds with the identification of the human rights the analysis zooms in on, as well as with the selection of the human rights conventions and related international supervisory mechanisms. The second part of the article proceeds with highlighting the parallels and differences between these three supervisory mechanisms and their supervisory practices, which will colour the extent to which the latter are comparable and can be fully compared. Furthermore, a more detailed overview is given of the subsequent twostep analysis of the supervisory practice of the selected international supervisory mechanisms: first, an analysis mechanism by mechanism; second, a comparison of the respective fault lines in these supervisory practices, including the respective strengths and weaknesses.

It is important to realise that, particularly for civil and political rights, positive state obligations have been identified through reliance on the effectiveness principle, namely the understanding that fundamental rights need to be real and effective, not theoretical or illusory. ${ }^{14}$ Over time, the overarching concern with the effective protection of fundamental rights has steered the interpretation of human rights and the related state obligations towards an ever more elaborate list of positive

12. Trispiotis, above n. 7, at 16 .

13. See, inter alia HRC, General Comment no 31, at paras. 7-8.

14. The ECtHR has developed a steady line of jurisprudence to this effect, see, e.g. Airey v. Ireland, ECHR Fair Balance: Proportionality, Subsidiarity and Primarity in the ECHR, Brill (2009), at 238. (1979) Series A, No. 6389/73, at para. 24; Artico v. Italy, ECHR (1980) Series A, No. 6694, 74, at para. 33; Mehmet Eren v. Turkey, ECHR (2008) Series A, No. 32347, at 2. The Human Rights Committee also refers numerous times to the effective protection principle in its supervisory practice, inter alia in General Comment no 31 on the Nature of the General Legal Obligation Imposed on State Parties to the Covenant. 
state obligations. ${ }^{15}$ The effectiveness principle is thus a key consideration throughout this article, which is also returned to when discussing the level of scrutiny that is adopted by international supervisory mechanisms.

When focusing on positives state obligations, it is important to highlight that the dividing line between negative and positive state obligations is not always that clear-cut, also because of the interaction between the public and the private sphere. Negative state obligations constrain public policies and actions. Still, public policies, even when formulated in neutral terms, can nevertheless be stigmatising (due to the overall context in which the policy is adopted) towards particular groups, further increasing societal intolerance against these groups. ${ }^{16}$ Put differently, the negative obligation not to adopt such stigmatising legislation goes hand in hand with positive state obligations to actively counter intolerance between groups. ${ }^{17}$

Since Islamophobia is described above as a particular state of mind (prejudice against Muslims) as well as the acts of discrimination informed by this state of mind, countering Islamophobia similarly has two strands, namely countering both the state of mind and the acts informed thereby. The sociological article in this special issue by Böcker has revealed that the answer to the question whether law can change the hearts and minds does not have a clear-cut answer. Law is primarily targeted at people's actions, which in turn may influence, over time, the way they actually feel about persons/things. Nevertheless, as was further developed in Berry's paper in this special issue, public authorities' have the power to regulate mechanisms that can have meaningful impact on the way people see others, including (public) education, through its socialisation function, and the media. ${ }^{18}$ Relatedly, public authorities can organise awareness-raising campaigns, and related campaigns aimed at different population groups coming together, and building shared experiences.

This article focuses on what a selection of international supervisory mechanisms has identified in terms of posi-

15. Inter alia, J.-F. Akandji-Kombe, Positive Obligations Under the European Convention on Human Rights: A Guide to the Implementation of the European Convention on Human Rights (Human rights handbooks, No. 7) Strasbourg, Council of Europe (2007).

16. International courts should reflect this interrelation between public policies and private intolerance in their review of the public policies concerned. See infra the critical analysis in relation to ECtHR case law in S.A.S v. France.

17. PACE Res. 1743 contains a very negative assessment of total bans on full-face veils in public, exactly because of the underlying exclusionary message.

18. For a further discussion of the importance of the right to education, see infra. Freedom of expression also benefits the media, but it is important to keep in mind that the exercise of the freedom of expression carries with it duties and responsibilities (see, inter alia Art. 10(2) ECtHR). In terms of minority-specific rights, these duties and responsibilities are further expanded upon, e.g. 9(4)FCNM which obliges state parties to adopted 'adequate measures in order to facilitate access to the media for persons belonging to national minorities and in order to promote tolerance and permit cultural pluralism'. Whilst not intending to discount the importance of media and their coverage of minorities, the analysis of this article does not expand upon the media. tive state obligations regarding fundamental rights, either explicitly in relation to manifestations of Islamophobia or having the potential to be used to counter Islamophobia. It will have regard to two strands of obligations, both obligations that concern countering acts of discrimination, and obligations that rather concern the proactive promotion of reducing prejudice itself, and thus more directly aimed at changing the hearts and minds.

As Islamophobia targets Muslims as members of an ethnic and or religious minority, it is surely relevant to consider the foundational principles of minority protection. These core concerns of minority-specific rights speak to the particular vulnerabilities minorities experience in terms of equality (effective protection against discrimination and right to substantive equal treatment), identity (right to respect for the separate minority identity) and participation. ${ }^{19}$ The broad range of manifestations of Islamophobia has revealed fundamental problems in relation to these three principles.

Given Islamophobia's intrinsic link to prejudice and discrimination against Muslims, particular attention will be had to the way in which the international supervisory mechanisms assess alleged instances of discrimination, be that direct or indirect discrimination. The prohibition of discrimination is crucially about preventing disadvantageous treatment based on prejudice, since the latter does not constitute a reasonable and objective justification. $^{20}$

Furthermore, several fundamental rights are of special relevance to (religious) minorities in themselves, and in combination with the prohibition of discrimination, so as to ensure the equal and effective enjoyment of these fundamental rights. The freedom of religion is obviously an important right that nurtures the right to a separate religious identity for persons belonging to religious minorities. Education has a key role to play in relation to the shaping of the society of tomorrow: It does not only have an important qualification function but also a vital socialisation function. Education's socialisation function is important for government in the sense that it is a crucial vehicle to pass national values and ways of life to the next generation, enabling them to function optimally in society. At the same time, education is also crucially important for minorities in the sense that they want protection against indoctrination, so that their right to a separate identity is not disregarded. Civil and political human rights law obliges public authorities to respect a parent's religious convictions throughout public education, which has repercussions for the content of the cur-

19. See, inter alia K. Henrard, 'Challenges to Participation in the Name of "Integration": Participation, Equality and Identity as Interrelated Foundational Principles of Minority Protection', in W. Romans, I. Ulasiuk and A. Thomson (eds.), Effective Participation of National Minorities and Conflict Prevention, The Hague, Martinus Nijhoff (2019), at 43-80. See also A. Verstichel, Participation, Representation and Identity: The Rights of Persons Belonging to Minorities to Effective Participation in Public Affairs: Content, Justification and Limits, Antwerp, Intersentia (2009).

20. See, inter alia www.coe.int/en/web/compass/discrimination-andintolerance. 
riculum and possible exemption schemes. ${ }^{21}$ Social human rights add that 'education shall ... strengthen the respect for human rights and fundamental freedoms ... promote understanding, tolerance and friendship among all nations and all racial, ethnic or religious groups'. ${ }^{22}$ To some extent, this protection against indoctrination, and the duty to have a pro-tolerance curriculum, strengthens the right to equal and effective access to education of minority children. ${ }^{23}$ Education's qualification function concerns the passing on of knowledge and qualifications, enabling one's participation in society. Equal and effective access to education is thus key to one's equal participation in society. Similarly, equal access to employment, and to public space at large, is essential for one's equal participation in society. This article focuses on three conventions and what the supervisory practice of their respective international supervisory mechanisms has clarified about the positive state obligations to counter Islamophobia and provide effective protection against discrimination and of the freedom to manifest one's religion, also in relation to access to public education, to employment and to public space at large. ${ }^{24}$ In light of that thematic focus in relation to a particular minority group, the following analysis focuses on the supervisory practice of three international human rights supervisory mechanisms, namely the Human Rights Committee (HRC; International Covenant on Civil and Political Rights (ICCPR)), the European Court of Human Rights (ECtHR) and the Advisory Committee of the Framework Convention for the Protection of National Minorities (AC/FCNM).

\section{International Supervisory Practice Concerning Positive State Obligations in Relation to Islamophobia: $\mathrm{HRC/}$ ICCPR, ECtHR, AC/FCNM}

Prior to zooming in on the analysis of the (fault lines of the) supervisory practice of these three selected mechanisms, it is important to highlight the respective differences and similarities between these mechanisms. There are various types of supervisory practice: complaints procedures, the review of periodic state reporting, and overarching (not state-specific) thematic documents. The ECtHR only has complaints procedures; the AC/FCNM reviews periodic state reporting, and devel-

21. Art. 18(4) ICCPR and Art. 2, protocol 1 ECHR.

22. Art. 13(1) ICESCR.

23. See, inter alia A Human Rights based Approach to Education for All, UNICEF 2007, 13

24. See also Human Rights Council Resolution $16 / 18$ on Combating Intolerance, Negative Stereotyping and Stigmatisation of, and Discrimination, Incitement of Violence and Violence against Persons based on Religion or Belief, A/HRC/RES/16/18, 12 April 2011, at paras. 1 and 6. ops thematic commentaries; and the HRC combines all three modalities of supervisory practice.

When international supervisory mechanisms' supervision happens through complaints procedures, this also means that the extent to which they can develop (quasi) jurisprudence, and provide clarification about the extent of state parties (positive) obligations, depends on the cases brought to them. Periodic state reporting, on the other hand, provides the opportunity to the supervisory mechanism to review the total picture of the extent to which and the way in which a state implements its obligations under the convention. To the extent that this review also takes into account NGO's shadow reports and conducts visits in the country under review, it allows the supervisory mechanism to conduct a rather searching and encompassing review. Furthermore, due to the recurring process of the review, this type of supervisory practice also allows the development of lines of supervisory practice that can be refined over subsequent review cycles, particularly when follow-up procedures are devised.

Only the ECtHR is an international court in the narrow sense, having the power to pronounce legally binding judgments. ${ }^{25}$ The HRC can also hear individual complaints against particular states, ${ }^{26}$ but its 'views' are not legally binding. Nevertheless, the de facto difference between legally binding judgments and not legally binding views of Treaty Bodies officially mandated to review compliance of state parties with their treaty obligations is becoming less visible. On the one hand, the pressure to comply with non-legally binding views is heightened through the public availability of these views and exposure by civil society (and media). On the other, in the end, states cannot be forced to comply with legally binding judgments; so also, here the political will to comply needs to be present (or created). ${ }^{27}$ The vast difference in quantity of case law of the ECtHR as compared to the HRC confirms the dependence of this type of supervisory practice on complaints being filed by applicants. The HRC can expand its supervisory practice through the review of periodic state reporting, and the adoption of general comments, that crystallise its supervisory practice in relation to a particular matter. ${ }^{28}$

The supervisory practice of the FCNM does not encompass complaints procedures, which limit the extent to which this practice directly can contribute to the effective protection of rights of particular complainants. Nevertheless, the review of periodic state

25. Art. 32 ECHR. See also Arts. 33 and 34 regarding individual and interstate complaints.

26. See ICCPR, First Optional Protocol.

27. See, inter alia N. Grossman, H.G. Cohen, A. Follesdal and G. Ulfstein (eds.), Legitimacy and International Courts, Cambridge, CUP (2018).

28. These general comments are not updated on an ongoing basis, and the general comments on the prohibition of discrimination (no 18) and on the freedom of religion (no 22) date back from 1989 and 1993, respectively. General comment no 31 on the Nature of the General Legal Obligation Imposed on State Parties to the Covenant dates back from 2004 and has been referred to above in relation to the effective protection principle. 
reporting does allow the Advisory Committee to develop - through its not legally binding opinions - lines of supervisory practice, as well as follow-up review. To the extent that these opinions are compiled on an article-byarticle basis per review cycle, ${ }^{29}$ it optimises the accessibility of these lines of supervisory practice, and the way these develop over the distinctive review cycles. Similarly, the development of so-called thematic commentaries crystallises this supervisory practice about a particular theme, such as education, and participation. ${ }^{30}$

The following parts analyse the selected supervisory practice in two steps; first, the selected practice of each supervisory mechanism is analysed (parts 3-5), after which a comparison is made of the fault lines of the respective supervisory practice (part 6). In the first step, the analysis of the supervisory practice starts with an assessment of the relevant baseline, after which the most relevant available supervisory practice, for this article, is reviewed. For the HRC (part 3), first the most relevant individual complaints are assessed, followed by the identification of lines of practice that become visible through the concluding observations (periodic state reporting). Subsequently, the relevant case law of the ECtHR is discussed (part 4), against the background of the general development lines of the Court's jurisprudence concerning the prohibition of discrimination and the freedom to manifest one's religion. While both the HRC and ECtHR have cases that concern the more latent forms of Islamophobia with impact on effective access to education (including requirements as to the content of the curriculum and exemption schemes), the public space at large and/or employment, the ECtHR, in addition, has a line of jurisprudence pertaining to discriminatory violence against religious minorities. The fifth part shifts the focus of analysis to the AC/FCNM. As the central features and related content of the FCNM is less well-known, the analysis of the supervisory practice of the AC/FCNM is preceded by a discussion of the most relevant provisions of the FCNM in relation to positive state obligations concerning Islamophobia.

When turning to the comparison of the fault lines in these supervisory practices, it is important to emphasise that these fault lines are not fully comparable because of the respective differences in the nature of supervisory practice. Nevertheless, a comparison at a higher level of abstraction remains possible, more particularly returning to the two strands of countering Islamophobia identified above: fighting instances of discrimination versus actively promoting understanding and respect of groups with a different identity, a Muslim identity in particular. Having regard to the respective strengths and weaknesses of the supervisory practice of these three international supervisory mechanisms, the article concludes with some overarching recommendations.

\section{The Human Rights Committee of the ICCPR and Islamophobia}

In line with the limited jurisprudence of the HRC, very few cases can be identified as directly or indirectly relevant to gauge the extent to which the Committee identifies positive state obligations to counter Islamophobia. Nevertheless, as the baseline attitude of the HRC to its supervisory role has positive repercussions for the extent to which it offers protection of Muslim minorities against Islamophobia, and measures infused by Islamophobia, an evaluation of this baseline in the HRC's case law is called for (3.1.1). Subsequently, cases concerning more latent forms of Islamophobia, namely neutral measures that amount to considerable limitations on the freedom to manifest the Muslim religion, are discussed (3.1.2). Thirdly, the attention shifts to the case law on state duties to respect the religious and philosophical convictions of the parents throughout public education (3.1.3). In addition, the review of the HRC's Concluding Observations (3.2) provides insights into what the HRC considers more generally important to contribute to the effective protection of the prohibition of discrimination and the freedom to manifest one's religion, also of relevance in relation to acts of Islamophobia.

\subsection{Individual Complaints}

3.1.1 Admittedly, the HRC supervising the ICCPR does not have a lot of cases on Article 18, ICCPR's freedom to manifest religion, nor cases brought in terms of Article 27, ICCPR's right not to be denied the right to profess and practice their own religion in community with the other members of their group. ${ }^{31}$ Waldman v. Canada is relevant to highlight in several respects. The claimant invoked the violation of Article 27, Article 26 ICCPR and Article 18 ICCPR because of the lack of public funding Canada made available to Jewish private schools, in contrast to the public funding of Catholic private schools. The Committee decided this case on the basis of Article 26 ICCPR, as a prohibited discrimination: ${ }^{32}$ A state does not have to provide public funding to private schools, but if it does so, it needs to proceed on a non-discriminatory basis; only providing public funding to one minority religion is not reasonable and objective. ${ }^{33}$ It would not be necessary to still evaluate the alleged violation of Article 18, ICCPR's freedom of religion, and Article 27 ICCPR. ${ }^{34}$ The HRC thus highlights the central importance of the right to equal treatment in the human rights paradigm: It first tries to

31. S. Berry, 'A Good Faith Interpretation of the Right to Manifest Religion? The Diverging Approaches of the ECTHR and the UNHRC', 37 Legal Studies 672, at 681 (2017).

32. HRC, Areah Hollis Waldman v. Canada, Communication No. 694/1996, CCPR/C/67/D/694/1996.

33. Ibid., at para. 10.5 .

34. Ibid., at para. 10.7 . 
settle cases on this ground. As is confirmed in the discussion of the cases directly relevant for the Islamophobia angle of this article, the HRC does not shy away from evaluating complaints in terms of the prohibition of discrimination.

Several of the HRC cases on the freedom of religion concern interferences by the states, and thus negative state obligations, not so much positive state obligations. Nevertheless, these cases merit some attention as they nicely reflect the rather high baseline scrutiny adopted by the HRC, resulting in elevated protection levels. ${ }^{35}$ The HRC each time engages in an in concreto analysis of the alleged threat, the appropriateness of the invoked legitimate aim, the suitability and the proportionality of the measure towards the legitimate aim. In relation to the French prohibition to wear religious headwear for identity cards, the HRC acknowledged the legitimate aim that a picture needs to allow identification but engaged in a critical proportionality review, underscoring that wearing a turban does not hide the face and is actually very representative as he wears this at all times. ${ }^{36}$ Similarly, the HRC does not accept the prohibition on wearing a keski, a small dagger to school, when this is a religious manifestation for Sikhs, while the keski does not pose a real threat to the rights and freedoms of other pupils or to order at the school. ${ }^{37}$

3.1.2 The HRC has more recently been confronted with cases that concern more latent forms of Islamophobia which impact on the effective access of Muslims to employment and the public space at large, more particularly of Muslim women who want to wear a headscarf or burqa. Admittedly, these cases concern the operation of acts of legislation and thus rather interferences by public authorities with fundamental rights. Nevertheless, the HRC's jurisprudence sends a clear message to states about the unacceptability of legislation which disproportionately limits the manifestation of the religion of particular religious minorities. On 17 July 2018 the HRC pronounced two views in similar cases against France, brought by women who wear the fullface veil for religious reasons and who complain about ${ }^{38}$ the French law criminalising the wearing of face-covering clothes in public. In Hebbadj v. France ${ }^{39}$ and Yaker v. France, ${ }^{40}$ the HRC concludes to a violation not only of the freedom of religion but also of the prohibition of discrimination, adopting in both respects a suitably strict scrutiny.

In relation to the former, the Committee accepts that in certain situations it may be necessary to see the face of persons in order to identify them, but public order arguments cannot uphold a total ban on face-covering

35. Berry, above n. 31, at 683

36. HRC, Ranjit Singh v. France, Communication No. 1852/2008, 4 February 2013, at para. 8.4

37. HRC, Bikgramiit Singh v. France, Communication No. 1852/2008, 1 November 2012, at para. 8.7.

38. Ibid., at para. 8.10

39. HRC, Hebbadj v. France, Communication No. 2807/2016, views of 17 July 2018, CCPR/C/123/D/2807/2016.

40. HRC, Yaker v. France, Communication No. 2747/2016, views of 17 July 2018, CCPR/C/123/D/2807/2016 clothes in public. ${ }^{41}$ France also invoked 'respect for the rights of others' because the ban would be necessary to ensure living together. The HRC does not accept the connection claimed by France between 'the rights of others' and living together, ${ }^{42}$ while the legislative ban would in any event not be proportionate, ${ }^{43}$ concluding to a violation of Article $18 .{ }^{44}$ The HRC continues its critical assessment when it proceeds with the discrimination complaint of the women. The legislative ban obviously has a disproportionate impact on (Muslim) women who want to wear a veil for religious reasons. The HRC does not stop its ${ }^{45}$ assessment of the complaint of indirect discrimination there, but also critically notes that because of the many exceptions the law contains, Muslim women who wear the burqa are left as the main addressees of the law, as is also confirmed by the enforcement of the law. ${ }^{46}$ Furthermore, the Committee emphasises that France does not provide any justification for the disproportionate manner in which the law is applied, which is even more problematic because criminal sanctions are imposed. ${ }^{47}$ In the end, the Committee concludes to intersectional discrimination based on gender and religion.

On 16 July 2018, the HRC also concludes to a violation of the freedom of religion and the prohibition of (intersectional) discrimination in F.A. v. France, ${ }^{48}$ on another individual complaint by a Muslim woman against France, this time complaining about a dismissal only because she is wearing a headscarf in a child care centre. Also, in this case, the HRC adopts a critical level of scrutiny both in relation to the legitimate aims invoked by the state, and of the alleged proportionality of the limitation. The Committee does not accept the argument that the prohibition of a headscarf at a child care centre would be necessary to secure the rights and freedoms of parents or children, since the wearing of a headscarf is not in itself proselytising. ${ }^{49}$ The Committee correctly highlights that the ban on wearing a headscarf at a child care centre has a stigmatising effect on the religious community concerned. ${ }^{50}$ Turning to the complaint that the internal regulation of the child care centre has a disproportionate impact on Muslim women, in violation of the prohibition of discrimination, the Committee acknowledges the disproportionate impact on the women of a particular religious community, and again highlights its concern about the feelings of exclusion and marginalisation this may cause for the group concerned. ${ }^{51}$ The Committee critically opines that France has not provided a sufficient reasonable and objective justification for the disproportionate impact on Muslim

41. Ibid., at para. 8.7.
42. Ibid., at para. 8.10.
43. Ibid., at para. 8.11.
44. Ibid., at para. 8.12 .
45. Ibid., at para. 8.17.
46. Ibid., at para. 8.13 .
47. Ibid., at para. 8.16 .
48. HRC, F.A. v. France, Communication No. 2662/2015, 16 July 2008.
49. Ibid., at paras. $8.8-8.9$.
50. Ibid., at para. 8.9 .
51. Ibid., at para. 8.12 .


women who want to wear the headscarf, thus again concluding to intersectional discrimination on grounds of religion and gender. ${ }^{52}$

3.1.3 Finally, considering the importance of education, and, more particularly, the values transposed through education for the future of society, and thus also for a societal project of changing the hearts and minds, regard should also be had to the provision on the state duties in relation to the content of the public curriculum. In terms of civil and political rights conventions, such as the ICCPR and the ECtHR, this is framed in terms of state duties to respect the religious and philosophical convictions of the parents throughout public education. ${ }^{53}$ Admittedly, this provision does not impose an obligation on states to adopt an inclusive curriculum, nor a curriculum that is geared towards the promotion of tolerance amongst population groups. Nevertheless, the HRC has a steady line of jurisprudence following which Article 18(4) implies a duty for public education to be neutral and objective, which would also imply protection against latent Islamophobia in the way the curriculum is constructed and applied.

In Leirvag et al. v. Normay, ${ }^{54}$ parents complain about a change in public education in Norway following which the curriculum now contains an obligatory course on Christianity and other religions, which disproportionately favours Christianity, includes too many practice elements and a complex and demanding system of partial exemptions. According to the parents, this would amount to a violation of their rights to have their religious convictions respected in the public education system. Following a critical assessment of the content of the course, the Committee concludes that this course is indeed not neutral, ${ }^{55}$ which shifts the focus to the exemption scheme. Since the Committee notes several shortcomings to the system of partial exemptions which would be too demanding on parents, and ultimately unable to address their substantive concerns, ${ }^{56}$ it concludes to a violation of Article 18, para. 4. While this case does not concern latent forms of Islamophobia creeping in the public curriculum, or the way the exemption scheme is operated, ${ }^{57}$ the critical review by the HRC implies a suitable check on any such potential developments.

\subsection{Concluding Observations}

The review of the HRC's Concluding Observations in relation to European countries in the past few years confirms the HRC's strong concern with the optimalisation of the effective enforcement and realisation of the prohibition of discrimination also in relation to Muslims. In its review of the non-discrimination provisions of the Covenant, ${ }^{58}$ the Committee is rather demanding about

52. Ibid., at para. 8.13

53. Art. 18, 4 ICCPR.

54. HRC, Leirvag et al. v. Norway, Communication No. 1155/2003, 3 November 2004.

55. Leirvag et al. v. Norway, above n. 54, at para. 14.5.

56. Leirvag et al. v. Norway, above n. 54, at paras. 14.6-14.7.

57. See infra on Osmanoglu and Kocabas v. Switzerland.

58. Arts. 2, 3 and 26 ICCPR. the need for comprehensive coverage of non-discrimination legislation, both concerning grounds and material fields of operation. ${ }^{59}$ Of relevance to the focus of this article, the HRC noted with concern - and asked Belgium to eliminate - the legislative and procedural distinction between the treatment of racist and xenophobic hate speech, on the one hand, and Islamophobic hate speech, on the other. ${ }^{60}$ Notwithstanding the lack of individual complaints about discriminatory violence before the HRC, a recurring theme in several of the HRC's concluding observations is the concern it expresses about the perseverance of hate crimes and hate speech against religious and ethnic minorities, and problems in investigation and prosecution thereof. ${ }^{61}$ In this regard, the HRC develops three lines of supervisory practice, one on the need to improve law enforcement to combat hate crimes and hate speech, the second one on state duties to actively promote tolerance among different population groups and/or to eradicate stereotypes. The third line focuses on ensuring adequate training of law enforcement officials, judges and prosecutors, and actually can be seen to strengthen the two preceding lines, which in turn correspond to the two strands of strategies that public authorities can adopt to counter prejudice against particular groups, identified in the introduction.

In addition to general statements concerning extra efforts regarding law enforcement, ${ }^{62}$ the HRC urges states specifically to 'develop an effective strategy, in cooperation with digital technology companies, to reduce online hate speech'63 and to develop 'effective programmes for addressing manifestations of racial discrimination and hate speech at public events, including football matches' ${ }^{64}$ The second line, regarding the state duties to promote tolerance amongst different population groups, at times does not go beyond the mere statement calling on the state to heighten its efforts to promote tolerance. ${ }^{65}$ At times, the HRC becomes more explicit by adding that the state should envisage 'measures to promote an environment inclusive of persons belonging to minorities, including with

59. See also K. Henrard, The Impact of International Non-discrimination Norms in Combination with General Human Rights for the Protection of National Minorities: Several United Nations Human Rights Conventions, DH-MIN (2006), at 02, W. van den Hole, Non-Discrimination and Equality in the View of the UN Human Rights Treaty Bodies, Antwerp, Intersentia (2005).

60. Concluding Observations on Belgium, 6 December 2019 , CCPR/C/BEL/CO/6, at para. 19.

61. Concluding Observations on Hungary, 9 May 2019, CCPR/C/HUN/CO/6, at para. 17; Concluding Observations on Norway, 25 April 2018, CCPR/C/NOR/CO/7, at para. 17.

62. Concluding Observations on Romania, 11 December 2017 CCPR/C/ROU/CO/5, at para. 44; Concluding Observation on Norway, 25 April 2018, at para. 17 (with specific focus on the need to improve the investigation capacity); Concluding Observations on Hungary, 9 May 2018, CCPR/C/HUN/CO/6, at para. 19; Concluding Observations on the Czech Republic, 6 December 2019, CCPR/C/CZE/CO/4, at para. 17(c)

63. Concluding Observations on the Netherlands, 6 December 2019 CCPR/C/NLD/CO/5, at para. 16.

64. Ibid.

65. Concluding Observations on Norway 2018, at para. 17. 
respect of their linguistic and cultural rights' ${ }^{66}$ In some concluding observations, the Committee elaborates on this further by calling on states to increase their 'efforts to eradicate stereotyping and discrimination ... among others by conducting public awareness campaigns to promote tolerance and respect for diversity'. ${ }^{67}$ In the third line, the HRC urges states to 'ensure adequate training on the promotion of racial, ethnic, and religious diversity' 68 and/or 'on addressing hate crimes' ${ }^{69}$ not only of law enforcement officials but also of judges and prosecutors. The HRC also highlights the important role of the media as regards both the avoidance of speech that can be used to instil fear of migrants and asylum seekers and to strengthen stereotypical prejudices based on ethnicity or religion ${ }^{70}$ and the active promotion of understanding and respect for minority groups. In the latter respect, the HRC recommends to states to provide training aimed at media workers on promoting racial, ethnic and religious diversity. ${ }^{71}$ Put differently, the HRC is crucially aware of the important role the media can play to influence public opinion, and thus potentially changing the hearts and minds, also in relation to Muslims. ${ }^{72}$

In line with its jurisprudence in Yaker v. France and Hebbadj v. France, the HRC is critical in its Concluding Observations about legislation that criminalises the wearing of garments that conceal the face (in the Netherlands and Belgium). The Committee does not only note that this ban risks disproportionately infringing the freedom to manifest one's religion but even acknowledges that this ban could increase the marginalisation of Muslim women in society. ${ }^{73}$ Similarly, the Committee notes that prohibitions to wear religious symbols at work, in certain public bodies and by teachers and students in public schools might entail violations of the freedom of religion and the prohibition of discrimination, which could enhance the marginalisation of religious minorities. ${ }^{74}$ The Committee thus demonstrates a keen awareness of the threats Islamophobia poses for the equal participation of Muslim minorities in society, and urges states to reconsider legislative bans with an Islamophobic undercurrent. ${ }^{75}$

66. Concluding Observations on Romania 2018, at para. 44.

67. Concluding Observations on Hungary, at para. 18. See also Concluding Observations on the Czech Republic, at para. 17, where the HRC calls for 'campaigns aimed at promoting respect for human rights and tolerance for diversity and revisiting and eradicating stereotypical prejudices based on ethnicity or religion'.

68. Concluding Observations on the Netherlands 2019, at para. 16

69. Concluding Observations on the Czech Republic 2019, at para. 17(d).

70. Ibid., at para. 16 .

71. Ibid.

72. Concluding Observations on Hungary 2018, at para. 17.

73. Concluding Observations on the Netherlands, at para. 58; Concluding Observations on Belgium, at para. 17

74. Concluding Observations on Belgium, at para. 17

75. Concluding Observations on the Netherlands, at para. 59; ibid., at para. 18.

\section{The European Court of Human Rights and Islamophobia}

The ECtHR is undoubtedly one of the most highly valued international human rights courts, whose jurisprudence often serves as a source of inspiration for other international and national courts. ${ }^{76}$ Nevertheless, some of its lines of jurisprudence are criticised, some of which concern the two fundamental rights most at issue in relation to Islamophobia, namely the prohibition of discrimination and the freedom to manifest one's religion. ${ }^{77}$ The analysis of the jurisprudence that is most relevant for the perspective of this contribution needs to be placed against the background of the typical features of the ECtHR's jurisprudence in relation to the two most relevant rights, the freedom to manifest one's religion and the prohibition of discrimination.

\subsection{ECtHR Jurisprudence in Relation to the}

Freedom of Religion and the Prohibition of Discrimination

The Court's jurisprudence regarding the freedom to manifest one's religion certainly has several promising features regarding positive state obligations to counter intolerance against particular religious groups. Indeed, the Court tends to underscore that the freedom of religion is centrally concerned with protecting and promoting religious pluralism and mutual tolerance, ${ }^{78}$ following which states are supposed to be neutral and impartial towards the multiple religions in its jurisdiction. ${ }^{79}$ This in turn has led the Court to highlight that in case of struggles or tensions between religions, states should not choose sides - they'd rather promote religious harmony and tolerance. ${ }^{80}$ It needs to be acknowledged though that the identification of these promising positive state obligations go hand in hand

76. References to ECtHR jurisprudence can be found in the judgements of the Inter-American Court of Human Rights and also several prestigious national courts such as the Canadian Supreme Court: Ricardo Canese v. Paraguay, Judgement, 31 August 2004, at paras. 89-90; Alberta v. Hutterian Brethren of Wilson Colony [2009] SCR 567 (Canada), at paras. 90, 128-131.

77. See Berry, above n. 31, and K. Henrard, 'How the European Court of Human Rights' Concern regarding European Consensus Tempers the Effective Protection of Freedom of Religion', 4(3) Oxford Journal of Law and Religion 398 (2015) and K. Henrard, 'The European Court of Human Rights, Ethnic and Religious Minorities and the Two Dimensions of the Right to Equal Treatment: A Jurisprudence at Different Speeds?', 34(03) Nordic Journal on Human Rights 157-77 (2016).

78. Inter alia, ECtHR, Metropolitan Church of Bessarabia v. Moldova, App no 45701/99, 16 December 2001. See also F. Tulkens, 'The European Convention on Human Rights and Church-State Relations: Pluralism v Pluralism', Cardozo Law Review 2579 (2009).

79. Noland and K v. Russia, ECHR (2009) Series A, No. 2512, 4, at para. 73. See also J. Murdoch, Council of Europe Human Rights Handbooks: Protecting the Right to Freedom of Thought, Conscience and Religion Under the ECHR, Strasbourg: Council of Europe (2012), at 8.

80. Hasan and Chaush v. Bulgaria, ECHR (2000) Series A, No. 30985, 96.; Metropolitan Church of Bessarabia v. Moldova, ECHR (2001) Series A, No. 45701, 99; Serif v. Greece, ECHR (1999) Series A, No. 38178, 97, at para. 53 
with the grant of a broad margin of appreciation. ${ }^{81}$ Furthermore, the Court has a long and steady line of jurisprudence granting states a broad margin of appreciation in relation to the broad category of church-state relations. ${ }^{82}$ It is important to highlight that the grant of a broad margin to states implies a particularly low level of scrutiny by the Court, which potentially undermines the effective protection of the freedom to manifest one's religion. ${ }^{83}$ While it has been argued more fully elsewhere that the Court de facto reduces the margin of appreciation concerning religious matters in those instances in which a noticeable European consensus can be denoted, ${ }^{84}$ this still leaves several controversies about which no such consensus exists. The numerous cases of prohibitions on wearing headscarves and the broad margin of appreciation left to states are a case in point. ${ }^{85}$

An important development in the Court's jurisprudence on the evaluation of allegedly neutral courses on religions and related exemptions needs highlighting, as this is related to parents' rights under Article 2 of the first additional protocol to the ECtHR to have their religious and philosophical convictions respected in the public education system. In Folgero v. Normay, the ECtHR departs from its traditional jurisprudence that left states a very broad margin of appreciation, to the extent that it allowed classes with a de facto dominant focus on the traditional religion of a state. Indeed, in Folgero, the Court, in line with the HRC's Leirvag decision, most critically assessed the course on religions and had concluded that there was both quantitatively and qualitatively much more focus on Christianity than on other religions. ${ }^{86}$ Following this critical assessment of the required neutrality of the public school curriculum, the Court emphasises the need for a proper system of exemptions. ${ }^{87}$ Also, here the Court critically assessed the partial system of exemptions in light of the need to effectively protect the rights of parents to ensure the education of their children in line with their own religious convictions, ${ }^{88}$ and concludes to a violation. ${ }^{89}$ The shift in the Court's jurisprudence implies that states need to make sure that any course on religions does not disproportionately focus on one religion, or does not discredit (one or more) minority religions.

81. As Murdoch underscores 'the maintenance of pluralism seems to be distinguishable from its active promotion': Murdoch, above n. 79, at 35.

82. Sindicatul 'Pa storul cel Bun' v. Romania, ECHR (2013) Series A, No. 2330, 9, at paras. 61, 133, 160 and 171; Hasan and Eylem Zengin v. Turkey, ECHR (2007) Series A, No. 1448, 4, at para. 63; Lautsi and others v. Italy, ECHR Grand Chamber (2011) Series A, No. 30814, 6, at para. 61.

83. See, inter alia, J. Christoffersen, Fair Balance: Proportionality, Subsidiarity and Primarity in the ECHR, Brill (2009), at 238.

84. For a detailed discussion and analysis, see Henrard (2015), above n. 77.

85. Inter alia Leyla Sahin v. Turkey; App no 44774/98, 10 November 2005, Dahlab v. France, App no 42393/98, 15 January 2001; Ebrahimian v. France, App no 64846/11, 26 November 2015.

86. Folgero and others v. Norway, ECHR (2007) Series A, No. 15472, 2, at paras. 90-95

87. Ibid., at para. 96 .

88. Ibid., at paras. 97-100.

89. Ibid., at para. 102.
Furthermore, for the longest time, the ECtHR's nondiscrimination jurisprudence was compared to Cinderella, as the Court tended to avoid evaluations of this prohibition as much as possible, and when it did engage in a non-discrimination analysis, it scrutinised lightly, thus not providing effective protection. ${ }^{90}$ Admittedly, over time, several improvements took place, such as the increasing recognition of suspect grounds of discrimination, triggering heightened scrutiny. ${ }^{91}$ However, so far the Court has avoided explicitly calling religion suspect in cases in terms of Article 9 plus $14 .{ }^{92}$ Admittedly, this does not mean that the Court does not provide proper protection against cases of invidious discrimination, particularly when the intolerance takes on violent forms, as is visible in the cases on religiously inspired violence against Jehovah's Witnesses. The string of cases against Georgia, a country known for the high levels of societal intolerance against and discrimination of Jehovah's Witnesses, show that the ECtHR becomes ever demanding in terms of positive state obligations to prevent, stop, prosecute and punish discriminatory violence by private parties. ${ }^{93}$ Furthermore, the Court's initial reticence to acknowledge and problematise the apparent state acquiescence and silent support of this private violence, was transformed in an identification of discriminatory intent and prejudice against Jehovah's Witnesses among the Georgian police. The Court actually established direct discrimination by the police, due to the general and documented practice of the

90. R. O'Connell, 'Cinderella Comes to the Ball: Article 14 and the Right to Non-Discrimination in the ECHR', 29(2) Legal Studies: the Journal of the Society of Legal Scholars 211 (2009).

91. Several promising developments are noted in the article of $\mathrm{O}^{\prime}$ Connell, above n. 90; Henrard (2016), above n. 77; O.M. Arnardottir, 'The Differences that Make a Difference: Recent Developments on the Discrimination Grounds and the Margin of Appreciation under Article 14 of the ECHR', 14 Human Rights Law Review 647 (2014). For an argument on the growing list of grounds that are considered suspect in terms of non-discrimination law, see also A.F. Bayefsky, 'The Principle of Equality and Non-discrimination in International Law', 11 Human Rights Law Journal 1, at 24 (1990).

92. The Court has hinted at the suspect nature of religion as ground of differentiation in cases on Art. 8 in combination with Art. 14 when a parent was refused custody because of the religious minority background: Hoffmann v. Austria, ECHR (1993), No. 12875, 87, at para. 36. More recently confirmed in Voinity v. Hungary, ECHR (2013) Series A, No. 29617, 7. Similarly, the Court is ever more critical about the need for non-discriminatory criteria and procedures concerning the registration and recognition of religions but this critical scrutiny is confined to Art. 9 after which no scrutiny in terms of Art. 14 would be necessary: Savez Crkava and others v. Croatia, ECHR (2010) Series A, No. 7798, 8, at para. 88. A noticeable exception in this respect is Izettin Dogan and others v. Turkey, ECHR (2016) Series A, No. 62649, 10, at paras. 170-173. Izettin Dogan as the Court actually did engage in a very promising and explicit non-discrimination analysis under Art. 14, building on the critical assessment of serious problems regarding the state duty of neutrality and impartiality under Art. 9, to highlight the need for 'particular scrutiny' of the less favourable treatment of the Alevi's under Art. 14 junctio 9.

93. Gldani Congregation of Jehovah's Witnesses and others v. Georgia, ECHR (2014) Series A, No. 71156, 1; Begheluri and others v. Georgia, ECHR (2014) Series A, No. 28490, 2; Tsartsidze ea v. Georgia, ECHR (2017) Series A, No. 18766, 4. 
police to condone private violence against this religious group. ${ }^{94}$

Notwithstanding the promising developments in relation to invidious discrimination, the Court still avoids a distinct non-discrimination analysis in cases of direct or indirect discrimination, when the complaint concerns the expression of a separate minority identity (about which no European consensus exists). ${ }^{95}$ In this respect, it is also considered unlikely that the Court would follow arguments about Islamophobia as a case of racial discrimination, since race triggers heightened scrutiny. ${ }^{96}$

\subsection{ECtHR Case Law 'Concerning'} Islamophobia

Notwithstanding the growing prevalence of Islamophobia in European societies, explicit acknowledgements by the Court of an Islamophobic context are strikingly sparse: ${ }^{97}$ So far, this only happened in one case, namely S.A.S. v. France. The Court has been criticised for not sufficiently acknowledging the Islamophobic context and using Islamophobia as a key contextual factor in its human rights analysis. ${ }^{98}$

In addition to the cases on religious discriminatory violence (against Muslims) (4.2.1.), several other cases of more latent Islamophobia are relevant, more particularly cases in which at first sight neutral measures are adopted/applied in an Islamophobic context and result in far-reaching limitations to the freedom to manifest the Muslim religion, disproportionately affecting Muslim women (4.2.2).

4.2.1 Regarding the former, the ECtHR's case law on Jehovah's Witnesses demonstrates a proper protection against hate crimes with a religious background, and has considerable potential in relation to Islamophobic hate crimes as well. Nevertheless, so far the Court does not seem to have transposed its reasoning and strictness of review regarding discriminatory violence against Jehovah's Witnesses to similar incidents against members of the Muslim minority. Karaahmed v. Bulgaria concerned a violent and severe disruption of the Friday prayer at the Mosque in Sofia, by a political party known for its anti-Islam attitude. Unfortunately, the Court avoided a discrimination analysis altogether, including the possi-

94. Compare the 2007 Gldani case, on the one hand with the 2014 Begheluri and 2017 Tsartsidze one. In the case of Tsartsidze, the Court did not only establish bias and prejudice against Jehovah's Witnesses among the police but also among judges: at paras. 84-88.

95. See the Court's reasoning in relation to Art. 14 inter alia in Winterstein v. France, ECHR (2016) Series A, No. 27013, 7; Yordanova and Others v. Bulgaria, ECHR (2012) Series A, No. 25446, 6; Cha'are Sialom ve Tsedek v. France, ECHR (2000) Series A, No. 27417, 95, at para. 87; Hamidovic v. Bosnia and Herzegovina, ECHR (2017) Series A, No. $57792,15$.

96. T. Loenen, 'Framing Headscarves and Other Multi-cultural Issues as Religious, Cultural, Racial or Gendered: The Role of Human Rights Law', NQHR 488 (2012).

97. Trispiotis, above n. 7, at 21-2.

98. Ibid., at 21. Trispiotis highlights that the Court 'as a result is liable to a heightened danger of majoritarian bias'. 98 Karaahmed v. Bulgaria, ECHR (2015) Series A, No. 30587, 13. ble discriminatory animus among the police, and did not identify a context of Islamophobia. ${ }^{99}$

4.2.2 Regarding the latter, Trispiotis noted that by 2018 the ECtHR has had roughly 40 cases brought by Muslim individuals, complaining about the violation of the freedom to manifest their religion and/or of the right not to be discriminated against on grounds of religion. ${ }^{100}$ In line with the preceding account of the Court's reluctance to engage in an explicit non-discrimination analysis when a case is intrinsically concerned with the expression of a distinct minority identity, most of these cases are dealt with in terms of Article 9's freedom of religion. ${ }^{101}$ Notwithstanding the worrying signs about increasing Islamophobia in Europe, as in the Western world generally, particularly since the terrorist attacks of 9/11 2001, ${ }^{102}$ there are hardly any explicit references to Islamophobia in the ECtHR case law. Since 2014, only two third-party interveners have highlighted the Islamophobic context of particular limitations to the freedom to manifest the Muslim religion. ${ }^{103}$ The Court itself has only once explicitly acknowledged the presence of an Islamophobic context, without, however, giving any weight to this context in the actual proportionality analysis. ${ }^{104}$ It is important to realise that the lack of explicit argumentation about an Islamophobic context does not mean that Islamophobia did not play (an important role) in other cases. The analysis of the Osmanoglu case below will demonstrate how Islamophobia, and related anxieties about the growing presence of the Muslim minority in a state, can be present in a more hidden form. Put differently, a close analysis of some of the older cases (prior to 2001) could similarly reveal early stages of Islamophobia, more particularly (most) cases pertaining to the wearing of headscarves. ${ }^{105}$

The following analysis zooms in on the two most prominent cases in which measures entailing restrictions on the freedom to manifest the Muslim religion were adopted in an explicit or at least implicit Islamophobic context.

S.A.S. v. France is the very famous first case in which the ECtHR was confronted with a piece of legislation, dubbed burqa ban, which criminalised the concealing of the face in public with garments.

The case was brought by a French Muslima who wears the burqa for religious reasons, invoking a violation of the freedom of religion and an indirect discrimination on grounds of religion, since the ban would dispropor-

99. Ibid.; L. Peroni, 'The (In)Visible Racial and Religious Motivation of Violence', Strasbourg Observers (27 March 2015), available at: https:// strasbourgobservers.com/2015/03/27/karaahmed-v-bulgaria-theinvisible-racial-and-religious-motivation-of-violence/ (last visited 30 September 2019)

100. Trispiotis, above n. 7, at 21-2, with reference to the Annex of his article where all the cases are enumerated.

101. Ibid.

102. See the credible reports referred to above n. 1 .

103. S.A.S v. France, Human Rights Centre of Ghent University, at para. 98; Dakir v. Belgium, NGO Liberty, at para. 35.

104. For a more detailed analysis, see infra on the S.A.S. v. France case.

105. Leyla Sahin v. Turkey would probably be the exception, since Turkey is a country with a dominant Muslim population. 
tionately affect Muslim women who want to conceal their face for religious reasons. While the Court is suitably critical towards several of the legitimate aims invoked by France, it did accept that the legislative ban served 'requirements of living together' which would qualify as the legitimate aim respect for the rights and freedoms of others. ${ }^{106}$ Strikingly, in its review of this legitimate aim, the Court notes itself with concern the information it received that the legislative discussions concerned were tainted by Islamophobic remarks. ${ }^{107}$ The Court noted that 'a state which enters into a legislative process of this kind takes the risk of contributing to the consolidation of stereotypes and of encouraging the expression of intolerance, while states actually have a duty to promote tolerance.' 108

Unfortunately, the Court develops at least three worrying lines of reasoning in this judgment, amounting to three failures to provide a counter narrative to the Islamophobia it has expressed concern about. ${ }^{109}$ Critical arguments can be formulated about the legitimate aim the Court accepts, the light proportionality review and the avoidance of a proper non-discrimination analysis. First of all, it is far from obvious that the Court would accept 'requirements of living together' as amounting to 'respect for the rights and freedoms of others', one of the exhaustively enumerated legitimate aims in Article 9 ECtHR. Indeed, who are 'the others' the protection of whose rights would legitimate an interference with the rights of Muslim women wanting to wear the full-face veil? The others can only refer to the majority population in France. The Court's acceptance of this majoritarian argument by the French government squarely contradicts the counter-majoritarian core of the entire fundamental rights paradigm. ${ }^{110}$ Secondly, when the Court proceeds to grant France a broad margin of appreciation, the Court extends the majoritarianism it introduced with the legitimate aim, thus producing a second failure to counter the underlying Islamophobia. Importantly, when evaluating the legitimate aim of 'living together', the Court had underscored that the flexibility of this notion entails the risk of abuse which would require a careful examination of the proportionality of the interference concerned. ${ }^{111}$ Unfortunately, when proceeding with the proportionality review the Court chooses to highlight and rely on reasons why France should still get a broad margin of appreciation, namely because it would concern a choice of society about which no European consensus exists. ${ }^{112}$ The third

106. S.A.S. v. France, ECHR (2014) Series A, No. 43835, 11, at para. 122. In the meantime, two similar cases against Belgium (both decided 11 July 2017, have resulted in similar defences by Belgium with the ECtHR confirming its (troubling) argumentation in S.A.S.: Dakir v. Belgium and Belcacemi and Oussar v. Belgium.

107. S.A.S. v. France, at para. 149.

108. Ibid.

109. See also Trispiotis, above n. 7, at 21.

110. K. Henrard, The Ambiguous Relationship between Religious Minorities and Fundamental (Minority) Rights, Boom Eleven International (2011), at $19-34$.

111. S.A.S. v. France, at para. 122.

112. Ibid., at paras. 154-156. failure to counter the underlying Islamophobia lies in the Court's refusal to engage in a distinct, proper nondiscrimination analysis. Indeed, the Court swiftly dismisses the non-discrimination complaint with a simple reference to the reasons it has adduced to conclude to a non-violation of Article 9 ECtHR. ${ }^{113}$ The Court thus extends the majoritarian reasoning it introduced under Article 9 to Article 14 junctio 9. Put differently, in a situation the Court itself notes as being tainted by Islamophobia, and thus prejudice against the Muslim minority, ${ }^{114}$ instead of giving pride of place to the prohibition of discrimination, and being extra vigilant when scrutinizing the discrimination complaint, the Court further demotes this norm notwithstanding its central role for the human rights paradigm. ${ }^{115}$

Osmanoglu and Kocabas v. Smitzerland is at first sight a very different case as it does not concern the criminalisation of the wearing of garments with religious connotations. It does concern the limitation of the rights of Muslim parents to have their daughters, for religious reasons, exempted from mixed swimming classes, a compulsory course in the public school concerned. When the parents persisted in their refusal to let their girls take part in the mixed swimming classes, they were fined. The parents claimed the violation of their right to manifest their religion. ${ }^{116}$ The government justifies the interference in the parents' rights as necessary for respect of the rights of others, more particularly the social integration of foreign children from different cultures and religions, and to protect them against every phenomenon of social exclusion. ${ }^{117}$ There is no comparable case of biased law making as in S.A.S, but the highest Swiss Court had explicitly noted in relation to this case that the concern about social integration is particularly relevant for the Muslim minority, as it has grown so exponentially over the years. ${ }^{118}$ This may not constitute outright Islamophobia; the Muslim minority is conceived as a threat to the integrity of the Swiss society. When the highest national Court expresses such a concern, this arguably reflects a broader societal context of unease about the Muslim minority in Switzerland.

Unfortunately, the Court's reasoning in several respects constitutes a failure to address the underlying negative sentiment about the Muslim minority. First of all, accepting as legitimate aim 'respect for the rights of others' the argument about the need to optimise the social integration of foreign children from different cul-

113. Ibid., at paras. 161-162

114. See also L. Peroni, 'Religion and Culture in the Discourse of the ECtHR: The Risk of Stereotyping and Naturalising', 10 International Journal of Law in Context 215 (2014).

115. See also Trispiotis, above n. 7, at 26-9.

116. Since Switzerland has not ratified the first optional protocol, including the provision on the right of parents to have their religious convictions respected throughout public education, the Court needs to address this complaint in light of Art. 9 ECHR.

117. Osmanog/u and Kocabas v. Switzerland, ECHR (2017) Series A, No. 29086, 12, at para. 31.

118. Decision of the Swiss Federal Tribunal (2008) BGW 135179. 
tures and religions, again constitutes majoritarian reasoning, since the rights of the minority are opposed to the interests of the majority in an integrated society. This majoritarianism is again extended through the Court's grant of a wide margin of appreciation, resulting in a minimal level of scrutiny of the interference concerned. Admittedly, the Court cannot evaluate this matter in light of protocol 1, Article 2; nevertheless, it is quite striking that the Court does not undertake any effort to evaluate the actual tension between a mixed swimming class and the religious convictions of parents, nor the impact of the extremely restricted exemption scheme used in the public school concerned.

Arguably, what both these cases show is that the ECtHR does not guide states towards tolerance, but rather confirms the Islamophobic attitude of the governments, ${ }^{119}$ thus allowing the majority to be intolerant towards the manifestation of the Muslim identity, which in turn may actually fuel Islamophobia. ${ }^{120}$ Furthermore, the lack of engagement with the explicit or implicit ${ }^{121}$ discrimination complaint by the claimants seems ill placed: Particularly in the European societies with the increasing prevalence of Islamophobia, one would expect a human rights court to take every opportunity to deploy the prohibition of discrimination, heed and employ signs of an Islamophobic context in the evaluation of a disproportionate application of neutral rules that seem to target Muslims. ${ }^{122}$

Sadly, two more recent cases on limitations to wearing the headscarf confirm the Court's lack of using Islamophobia as a relevant contextual factor in its human rights analysis. Both cases concern limitations on the wearing of the headscarf in the Court setting, one by a witness (Hamidovic v. Bosnia Herzegovina) and one by a civil party in a criminal case (Lachiri v. Belgium). ${ }^{123,124}$ Importantly, the Court did establish a violation of Article 9, thus helpfully indicating limits to the extent to which states can limit religious dress in public settings. Nevertheless, the Court still chose not to engage in an explicit non-discrimination analysis, ${ }^{125}$ notwithstanding

119. See also Peroni (2014), above n. 114, at 215-6.

120. See also S. Gohir, 'The Veil Ban in Europe: Gender Equality or Gendered Islamophobia', 24 Georgetown Journal of International Relations 30-31 (2015); K. Brayson, 'Of Bodies and Burkinis: Institutional Islamophobia, Islamic Dress and the Colonial Condition', 46 Journal of Law and Society 80-81 (2019).

121. Osmanog/u and Kocabas v. Switzerland, above n. 117, at paras. 61 and 96. The parents in Osmanog/u and Kocabas v. Switzerland had not formulated an explicit discrimination complaint, but they had argued that the exemption scheme in the public school had been implemented in a discriminatory fashion, as they alleged that exemptions asked by Christian Orthodox parents had been approved. The Court simply notes that the parents had not supported their claims by adequate proof.

122. See also Trispiotis, above at n. 7, at 32-3.

123. Hamidović v. Bosnia and Herzegovina, ECHR (2017) Series A, No. 57792, 15, at para. 40.

124. Lachiri v. Belgium, ECHR (2018) Series A, No. 3413, 09.

125. In Hamidovic v. Bosnia Herzegovina, the Court opined that following the establishment of a violation of Art. 9, it would no longer be necessary to evaluate the Art. 14 complaint (at para. 47). Lachiri v. Belgium the plaintiff did not raise an Art. 14 complaint before the ECtHR but she has done so before the national courts, so that the ECtHR could have requalified her complaint, following the jura novit curia adagio. the clearly Islamophobic context in which the application of neutral rules has a disproportionate impact on women wearing Islamic headscarves. Indeed, it is impossible to miss the elevated levels of Islamophobia in Belgium, while the Bosnian genocide in the territory of Bosnia Herzegovina targeted Muslim Bosnians, and anti-Muslim sentiments in the region have been noted to be on the increase. ${ }^{126}$ Both of these cases raise interesting questions about disproportionate applications of neutral rules that seem to point to the targeting of Muslims. The Court's failure to address these questions ignores the underlying Islamophobia, instead of providing the much-needed counter narrative.

\section{The Framework Convention for the Protection of National Minorities and Its Advisory Committee}

The preamble to the FCNM highlights the importance of an adequate protection of minorities for peace and stability in Europe, while highlighting that a climate of tolerance and dialogue needs to be created so that cultural diversity is a source of enrichment, not of division for each society. The preamble also clarifies that in the end the FCNM is about ensuring that the fundamental rights of minorities are fully and effectively protected, while building on United Nations (UN) and Organisation for Security and Cooperation in Europe (OSCE) standards in this respect. The preamble thus already identifies the foundational principles and the ultimate goals of the FCNM and minority protection, namely equality, identity and participation, aimed at the inclusion of minorities in national society. The FCNM can be seen to be built on three pillar provisions: ${ }^{127}$ Article 4 on full and effective equal treatment of persons belonging to minorities, Article 5 on the right to respect for the separate minority identity and Article 6 on the inclusion/integration of minorities.

\subsection{Possibly Relevant Provisions FCNM}

When considering the explicit provisions of the FCNM that concern state duties to counter intolerance and prejudice against national minorities, there are two that require special attention, namely Article 6 and 12 FCNM. Article 6 indeed obliges state parties to

126. See, inter alia the EU-funded European Islamophobia Report 2018 available at: www.islamophobiaeurope.com/wp-content/uploads/ 2019/09/EIR_2018.pdf.

127. Arts. 4-6 are the first three articles of Section II, containing the substantive articles of the FCNM Section I concerns the 'location' of the FCNM in the broader field of human rights and international law; Section III pertains to possible limitations and restrictions, whilst Section IV outlines the supervision system of the FCNM and Section $V$ ratifications, denunciations, etc. 
encourage a spirit of tolerance and intercultural dialogue, and take effective measures to promote mutual respect and understanding and co-operation among all persons living on their territory, irrespective of those persons' ethnic, cultural, linguistic or religious identity, in particular in the fields of education, culture and the media.

The relevant educational article, Article 12(1) FCNM identifies state obligations in relation to the public curriculum, more particularly to 'take measures in the fields of education and research to foster knowledge of the culture, history, language and religion of their national minorities and of the majority'. The Explanatory Report to the FCNM clarifies that Article 12 FCNM 'seeks to promote knowledge of the culture, history, language and religion of both national minorities and the majority population in an intercultural perspective. The aim is to create a climate of tolerance and dialogue' (emphasis added). Article 12(1) FCNM clearly aims at an inclusive educational setting, in which the distinctive groups are taught together, in a spirit of tolerance and mutual understanding. Inclusive, multicultural education is furthermore promoted by state duties to facilitate contact between students and teachers of different communities (Article 12(2) FCNM) and state duties to promote equal access to education at all levels for minority students (Article 12(3) FCNM).

Given the close link between discrimination on the one hand, and the underlying stereotypes, prejudice and intolerance on the other, one would expect extensive attention to problems of Islamophobia in relation to Article 4 (equality) FCNM. Similarly, as Islamophobic acts and policies often imply limitations to the freedom of religion, attention to Islamophobia is similarly envisaged in the supervisory practice under Article 8 FCNM.

\subsection{FCNM Supervisory Practice Countering Islamophobia: Articles 6 and 8 FCNM}

When reviewing the $\mathrm{AC} / \mathrm{FCNM}$ supervisory practice, it is striking that for two of these four articles, there is (virtually) no attention to Islamophobia and Muslims as minority, more particularly Articles 4 (equality) ${ }^{128}$ and 12 (3) (education, curriculum) FCNM. ${ }^{129}$ The AC/ FCNM does contain elaborate attention for Islamophobia and state duties to counter this in terms of Articles 6 (integration, inclusion) and 8 (freedom of religion) FCNM.

In relation to Article 6 , the Committee highlights the inhibiting impact of prejudice, in the sense that prejudice can block equal access to jobs and socio-economic participation more generally. ${ }^{130}$ The AC does not shy away from identifying clear state obligations to combat stereotypes and prejudice and to promote tolerance and

128. Compilation 3rd cycle Art. 4, has only four references to Muslims (next to other groups, such as Roma), and only one to Muslims specifically. Strikingly, the references to stereotypes all concerned Roma.

129. Compilation 4th cycle and 3rd cycle Art. 12 does not feature the word Islam or Muslim, at all.

130. Compilation 4th cycle Art. 15, Opinion on Finland, at 20. intercultural dialogue throughout society as a whole. ${ }^{131}$ In relation to Muslims, the AC notes with concern that many stereotypes are at play, often impeding the manifestation of their religion. ${ }^{132}$ In this respect, the $\mathrm{AC}$ recommends to state parties to make active efforts to improve dialogue between Muslims and non-Muslims and to fight intolerance and Islamophobia. ${ }^{133}$ Governments are urged to be vigilant that public discourse, e.g. against wearing the hijab in public spaces, does not fuel Islamophobia. ${ }^{134}$

Also, in terms of Article 8 on the freedom to manifest the minority religion, there is considerable attention for problems of Islamophobia and discrimination of Muslims. The AC problematises several forms of intimidation such as raids by the police, and insults and attacks against people who wear religious clothes, and places these restrictions in an Islamophobic context. The Committee correctly highlights that these disproportionate restrictions have a stifling effect on the manifestation of Islam, making the practice of the Muslim religion more complicated. Insofar as these restrictions originate from public authorities, they are not only problematic in themselves but also contain a symbolic message to society at large, disfavouring the Muslim population group, 'othering' them. ${ }^{135}$ This carries the risk of influencing the public at large, feeding into pre-existing stereotypes about Muslims, with the concomitant exclusionary effects. Insofar as these restrictions originate from private persons (insults and attacks related to manifestations of the Muslim religion), the AC identifies positive state obligations to develop legislation prohibiting such actions, and enforcing these prohibitions. ${ }^{136}$

131. Compilation 4th cycle Art. 6, Opinion on Czech Republic, at 14. Compilation 3rd cycle Art. 6, Opinions on Moldova, at 44, Slovak Republic, at 52 and Spain, at 54-6.

132. Compilation 4th cycle Art. 6, Opinion on Austria, at 6. The AC highlights in the Compilation of opinions under Art. 6 from the 3rd cycle, inter alia that public debate against particular manifestations of Muslim religion, such as ritual slaughter and the wearing of headscarves, can be seen to reveal anti-Muslim sentiments and undermine a culture of dialogue: Council of Europe, 'Compilation of Advisory Committee Public Opinions from the 3rd cycle relating to Article 6 of the Framework Convention for the Protection of National Minorities' (hereafter: Compilation 3rd cycle Art. 6) (13 May 2016), Opinion on Azerbaijan, at 5; Opinion on Russian Federation, at 19 and Opinion on Ukraine, at 21. AC/FCNM Compilation of Opinions of the AC relating to Art. 6 of the FCNM (Third Cycle), May 2016, at 86-7 (Moldova). Available at: https://rm.coe.int/CoERMPublicCommonSearchServices/ DisplayDCTMContent?documentld=09000016805a99fo. AC/FCNM Compilation of Opinions of the AC relating to Art. 6 of the FCNM (Fourth Cycle), September 2017, at 6-7 (Austria), 26 (Germany) and 54-5 (Spain). Available at: https://rm.coe.int/ CoERMPublicCommonSearchServices/DisplayDCTMContent? documentld=0900001680648f59.

133. Compilation 3rd cycle Art. 6, Opinion on UK, at 152-215

134. Compilation 3rd cycle Art. 6, Opinion on Spain, at 133.

135. The AC problematises several other disproportionate restrictions by public authorities, such as limiting the availability of burial sites and funeral services, the regulation of religious holidays, and restrictions on additional places of worship: AC/FCNM Compilation of Opinions of the AC relating to Art. 8 of the FCNM (Third Cycle), May 2016, at 6 (Bulgaria), 15 (Moldova) and 17-18 (Russian Federation). Available at: https://rm.coe.int/CoERMPublicCommonSearchServices/ 136. Ibid. 


\subsection{Existing Lines of FCNM Jurisprudence That} Could Be Used in Relation to Islamophobia

The AC could develop this 'Islamophobia' awareness also in relation to other FCNM articles, in line with several of its overarching lines of jurisprudence.

The AC/FCNM tends to underscore that governments should attach a positive value to diversity and different identities in society, diversity being represented as something that should be embraced, not something that should be shunned or eliminated. State parties are even urged to protect and promote the image of national society as an inclusive society. ${ }^{137}$ Furthermore, the AC exhibits a keen understanding of what is presupposed for the effective enjoyment of rights, for the importance of measures that are needed to make rights accessible and effective. Arguably, state obligations to counter prejudice and intolerance against particular groups, blocking these groups' effective participation in society, nicely fits in this strand of thinking.

In relation to Article $4 F C N M$ on equality, the AC's supervisory practice has recurring themes that also work in favour of improving Muslims' effective protection against discrimination. The AC is rather demanding about the legislative framework that needs to be in place, encompassing all relevant grounds, including religion and race/ethnicity, and having a broad material scope of application. ${ }^{138}$ In addition, this equality legislation needs to be properly monitored, special attention going to the establishment of equality bodies, with sufficient competences and resources. ${ }^{139}$ The AC furthermore highlights state duties to combat intolerance and promote mutual understanding (in line with Article 6 FCNM) and even urges states to develop campaigns to eradicate stereotypes. ${ }^{140}$ Nevertheless, as it stands, these general obligations are extensively developed in relation to Roma, but not (yet) in relation to Muslims. ${ }^{141}$ Put differently, the general awareness of the importance of public authorities' active engagement in campaigns to counter intolerance and prejudice in order to give effect to state obligations under Article 4 FCNM have not yet been translated in positive state obligations to counter Islamophobia. The potential is there though.

Similarly, the AC has developed steady lines of jurisprudence in terms of Article 12 FCNM (as combined with Article 6) about the importance of an inclusive, multicultural curriculum, which encourages tolerance, dialogue and mutual understanding amongst the differ-

137. The AC, e.g. urges states to overcome linguistic barriers of national minorities to effective access to public services by making the public service more multilingual: Compilation 4th cycle Art. 15, Opinion on Moldova, at 32; Compilation 4th cycle Art. 15, Opinion on Finland, at 21; Compilation 4th cycle Art. 15, Opinion on Hungary, at 25; Compilation 4th cycle Art. 15, Opinion on Moldova, at 32

138. Compilation Art. 4 - Cycles 3 and 4.

139. Ibid

140. Compilation Art. 4, Cycles 3, at 61 and at 90.

141. When reviewing the Compilation of views on Art. 4 of the 3rd and 4th cycles, the AC views tend to have a separate heading on Roma, and most talk about stereotypes is formulated in relation to Roma. Somehow there are only a few references to Muslims: the exception in cycle 3 , at 60 and 97. ent groups living together in society, ${ }^{142}$ ultimately promoting the teaching of the different groups together. ${ }^{143}$ The AC's Thematic Commentary on Education follows Article 29 of the UN Convention on the Rights of the Child (CRC) in this respect. ${ }^{144}$

While the AC has not been explicit about a place for Islam in the curriculum in this respect, it regularly underscores throughout its opinions the importance of an inclusive curriculum, promoting respect for religious diversity, and combating stereotypes affecting religious and ethnic groups. ${ }^{145}$ The AC furthermore urges state parties to regularly review curricula and textbooks, ${ }^{146}$ so as to ensure that the entire curriculum reflects the diversity of religious and ethnic identities. ${ }^{147}$ Furthermore, the AC emphasises the importance of religion as element of identity to be taken into account when promoting multicultural and intercultural education, and, ultimately, equal access to education in an atmosphere of tolerance. ${ }^{148}$ Unsurprisingly, the AC's Thematic Commentary on Education similarly aims at promoting effectively equal access to education of religious minorities, which is facilitated through the multicultural content of the curriculum, also having regard to the distinctive religions of minorities. Hopefully, the AC can apply in the upcoming supervision cycles this general line of reasoning also in favour of Islam, promoting the understanding of this religion, and thus the equal and effective inclusion of Muslim minorities in public education. Finally, when exploring the potential of the FCNM to counter Islamophobia and identifying positive state obligations in this respect, it is important to also have regard for the transversal importance of Article 15 FCNM on

142. Advisory Committee on the Framework Convention for the Protection of National Minorities - Opinion on the Netherlands (25 June 2009) ACFC/OP/I(2009)002, at para. 56. See also Second Opinion on Switzerland (2 September 2008) ACFC/OP/II(2008)002, at para. 85; Opinion on Germany (1 March 2006) ACFC/OPII(2006)001, at para. 88.

143. Thematic Commentary No.1 on Education, at 16-17

144. The Hague Recommendations regarding the Education Rights of National Minorities promoted by the HCNM similarly highlight the importance of an inclusive curriculum, in the sense that the teaching of histories, cultures and traditions of their respective national minorities should be included. This type of curriculum is depicted as essential for the promotion of tolerance and multiculturalism (paras. 19-20).

145. Council of Europe, 'Compilation of Advisory Committee Public Opinions from the fourth cycle relating to Article 6 of the Framework Convention for the Protection of National Minorities' (hereafter: Compilation 4th cycle Art. 6) (18 September 2017), Opinion on Denmark, at 15 and Opinion on FYROM, at 39. See also OSCE High Commissioner on National Minorities (HCNM), 'Ljubljana Guidelines on Integration of Diverse Societies' (7 November 2012) at 54.

146. AC/FCNM Compilation of Opinions of the AC relating to Art. 12 of the FCNM (4th Cycle), September 2017, at 11; AC/FCNM Compilation of Opinions of the AC relating to Art. 12 of the FCNM (3rd Cycle), May 2016, at 24-25.

147. Thematic Commentary No. 1 on Education, at 11. AC/FCNM Compilation of Opinions of the AC relating to Art. 12 of the FCNM (3rd Cycle), May 2016, at 13-14 (Bosnia-Herzegovina); AC/FCNM Compilation of Opinions of the AC relating to Art. 12 of the FCNM (4th Cycle) September 2017, at 9-12 (Cyprus) and 41 (Northern Ireland)

148. Thematic Commentary No. 1 on Education, at 15-16. AC/FCNM Compilation of Opinions of the AC relating to Art. 12 of the FCNM (4th Cycle), September 2017, at 39 (FYROM). Available at: https:// rm.coe.int/CoERMPublicCommonSearchServices/ DisplayDCTMContent?documentld=0900001680648f93. 
participation and participatory rights of minorities, not in the least because of its close interrelation with Article 4 on real and effective equality for persons belonging to minorities. ${ }^{149}$ The reach of participatory rights encompasses not only political participation but also socioeconomic participation, and, ultimately, participation in society at large. ${ }^{150}$ When combining these participatory rights with the pillars of the FCNM, namely equality, identity and participation/inclusion, this would protect and promote the full inclusion of minorities, with their distinct identity, as component part of society, on an equal footing with members of the majority. ${ }^{151}$ As with Articles 4 and 12 FCNM, so far Islamophobia has not received much attention in terms of Article 15 FCNM. Nevertheless, the above-mentioned baseline understanding of Article 15 FCNM and its implications clearly has potential to counter acts/policies with an Islamophobic undercurrent, such as indirectly discriminatory measures that de facto exclude minorities from society, from public life and from public education.

\section{Comparison of Fault Lines in the Jurisprudence of the Three International Supervisory Mechanisms}

Islamophobia, like xenophobia, points to deep-seated, ingrained discrimination against a particular group, whose effective enjoyment of fundamental rights is impaired. This in turn triggers the human rights obligations of liberal democratic states, more particularly states' positive obligations to ensure that fundamental rights are effectively enjoyed, and thus also respected in private, horizontal relationships.

As states, positive human rights obligations are not absolute but are constrained by reasonability considerations (what can one reasonably expect from a government), and by possible conflicting fundamental rights and related state obligations, this raises difficult questions about the extent to which and the way in which states would be obliged to counter Islamophobia, and particularly the underlying prejudice.

As highlighted in the introduction, when conceiving of strategies that states could adopt in order to counter Islamophobia., roughly two strands come to mind: On the one hand, the active promotion of tolerance, inter alia through awareness-raising campaigns and the stimulation of intercultural dialogue; on the other, counter-

149. Explanatory Note to FCNM (1995) H(95)10, at para. 80

150. See, inter alia Advisory Committee on the Framework Convention for the Protection of National Minorities Commentary on the Effective Participation of Persons Belonging to National Minorities in Cultural, Social and Economic Life and in Public Affairs, ACFC/31DOC(2008)001, 27 February 2008.

151. See also F. Palermo, 'The Dual Meaning of Participation: The Advisory Committee's Commentary to Article 15 of the FCNM', European Yearbook of Minority Issues 412 (2007/8). ing acts informed by intolerance, bringing the nondiscrimination strategies to mind, including the prevention/halting/punishment of discriminatory violence. Reviewing the relevant standards and the related supervisory practice of three international supervisory mechanisms has shown that the first strand is markedly less developed in terms of human rights law, especially in terms of explicit standards that easily allow through interpretation to identify positive state obligations to promote tolerance. Indeed, it is mainly in the FCNM, in some of the minority-specific standards that explicit references can be found to positive state obligations to encourage a spirit of tolerance and intercultural dialogue. Notwithstanding these promising explicit references to state duties to counter intolerance, it has been noted that the AC/FCNM supervisory practice has not yet fully embraced all its potential to counter Islamophobia and identify positive state obligations to counter it, more particularly in relation to the equality and the educational themes.

Still, the acknowledgement of the crucial importance of education for the promotion of tolerance, including the content of the curriculum and the extent to which the educational system is geared towards educating the different groups together, brings the educational provisions in general human rights conventions to the fore. After all, education concerns the future generations, and is generally a key concern for both minorities ${ }^{152}$ and the majority society. The supervisory practice, in terms of the ECtHR and ICCPR, has developed a more outspoken concern about indoctrination, and scrutinises states' choices in terms of curriculum stricter so as to prevent too one-sided an attention to one particular (dominant) religion. Nevertheless, no state obligations in terms of an inclusive curriculum have been identified as yet, nor the possible implications for religious dress and mixed swimming in public schools. The HRC's strict approach towards the legitimacy of limitations to the enjoyment of fundamental rights has managed to provide space for the expression of Muslim religion in the public school environment though.

When turning to the second strand, that of countering acts of intolerance, and the related anti-discrimination strategies, a rather mixed picture emerges. The baseline strict level of scrutiny adopted by the HRC appears to entail the highest level of actual protection against acts of intolerance infused by Islamophobia, also the more hidden forms of intolerance, in contrast to the overall disappointing record of the ECtHR. The AC/FCNM's religious sensitive approach leads to promising supervisory practice in terms of Article 8's freedom of religion, but is neither matched by the supervisory practice in terms of the FCNM's prohibition of discrimination nor the educational rights.

152. Minority-specific instruments always have ample attention for education, as does the supervisory practice, including any thematic recommendations or commentaries: the HCNM sponsored The Hague Recommendations on Education Rights of persons belonging to National Minorities, and the AC/FCNM Thematic Commentary on Education are documents in point. 
The HRC's jurisprudence reveals that with a strong baseline protection against interferences with fundamental rights, pricking through prejudice, a strong protection against Islamophobia is forthcoming also when one does not acknowledge the Islamophobic context. The HRC's willingness to engage in non-discrimination analysis also implies an openness to recognise intersectional discrimination, which is often at play in case of Islamophobia. ${ }^{153}$ The multiple criticisms against the ECtHR's jurisprudence regarding the freedom of religion and the prohibition of discrimination remain valid in relation to its case law on cases with an Islamophobic undertone. Indeed, in these cases, the Court miserably fails to give due weight to an Islamophobic context, while its majoritarian reasoning rubberstamps governments policies informed by Islamophobia, and it evades an actual non-discrimination analysis. Arguably, when an international supervisory mechanism does not have a strong baseline protection against interferences with fundamental rights, it is essential that an Islamophobic context is factored in explicitly in the human rights analysis, triggering heightened scrutiny for the freedom of religion, as well as an explicit non-discrimination analysis.

\section{By Way of Conclusion: Recommendations for International Supervisory Mechanisms Concerning the Identification of Positive State Obligations to Counter Islamophobia}

The convincingly documented and far-reaching human rights implications of Islamophobia make the question how far states' positive obligations extend to counter Islamophobia highly relevant. The preceding comparative analysis of the practice of three international supervisory mechanisms has revealed a rather mixed record and overall considerable scope for a clarification of positive state obligations to counter Islamophobia, regarding both of the possible strands of strategies of states to counter intolerance. The following recommendations are meant to contribute to the emergence of a more complete and coherent body of international supervisory practice regarding positive state obligations to counter Islamophobia.

In relation to the strand of active promotion of tolerance, the practice of international supervisory mechanisms could complement the scarce provisions in human rights instruments, explicitly imposing obligations to

153. Trispiotis, above n. 7, at 14. Argues that many cases of Islamophobia can be framed as cases of intersectional discrimination. promote tolerance, mutual understanding and intercultural dialogue. The use of systematic interpretation would be commendable here as this would enable the interpretation of general human rights in light of the overarching effectiveness principle while taking into account more elaborate and explicit human rights provisions on state duties to promote tolerance. Article 31(3)(C) Vienna Convention on the Law of Treaties (VCLT) indeed allows international supervisory mechanisms when interpreting a treaty to take into account the broader normative environment, including general international law and any relevant legal obligation. ${ }^{154}$ In relation to education, and the effective and equal access to education, the requirements in terms of an inclusive curriculum visible in the International Covenant on Economic, Social and Cultural Rights, the CRC and FCNM could inspire the interpretation of educational provisions in other conventions as well. Similarly, as elsewhere extensively argued, the right to equal treatment allows for an interpretation of the right to equal treatment as encompassing duties of reasonable accommodation also on grounds of religion. ${ }^{155}$ The related duties of differential treatment could also encompass the recognition of exemptions to general (neutral) rules, especially when not doing so would entail exclusions of particular religious groups, as we identified above in relation to Muslim minorities in Europe.

In relation to acts informed by intolerance, the international supervisory practice could highlight that in case of signs of an Islamophobic context, strict scrutiny of alleged violations of fundamental rights is called for, as well as an explicit non-discrimination analysis. The latter explicit engagement with the prohibition of discrimination would be in line with the higher risk of unlawful discrimination in an Islamophobic context. ${ }^{156}$ Furthermore, an Islamophobic context could work similarly as the presence of a suspect ground, thus triggering heightened scrutiny, including a more probing scrutiny to unveil hidden direct discrimination.

In the end, if international supervisory mechanisms would develop this more complete understanding of positive state obligations to counter Islamophobia, this would not only put states on notice that they should more proactively counter the underlying anti-Muslim prejudice but would also avoid any impression that these international supervisory mechanisms themselves are condoning or disregarding deep-seated discrimination against Muslim minorities in Europe.

154. Inter alia V.P. Tzevelekos, 'The Use of Article 31(3)@ of the VLCT in the Case Law of the ECtHR: An Effective Anti-Fragmentation Tool or a Selective Loophole for the Reinforcement of Human Rights Teleology? Between Evolution and Systemic Integration', 31 Michigan Journal of International Law 631 (2009-2010).

155. K. Henrard, 'Duties of Reasonable Accommodation on Grounds of Religion in the Jurisprudence of the European Court of Human Rights: A Tale of (Baby) Steps Forward and Missed Opportunities', 14(4) ICON (2016)

156. Trispiotis, above n. 7, at 32-3. 